\title{
Adopting SCRUM Framework in a Software Development of Payroll Information System
}

\author{
Bernadus Gunawan Sudarsono ${ }^{1}$, Fransiscus ${ }^{2}$, Henny Hartono ${ }^{3}$, Devi Yurisca Bernanda ${ }^{4}$, \\ Johanes Fernandes Andry ${ }^{5}$ \\ ${ }^{1}$ Information Systems Department, Universitas Bung Karno, Jakarta, Indonesia 10310 \\ Email : gunawanbernadus@ubk.ac.id \\ 2,3,4,5 Information Systems Department, Universitas Bunda Mulia, Jakarta, Indonesia 14430 \\ Email : ${ }^{2}$ frans_ant85@yahoo.com, ${ }^{3}$ hhartono@bundamulia.ac.id, ${ }^{4}$ dbernanda@bundamulia.ac.id, \\ 5jandry@bundamulia.ac.id
}

\begin{abstract}
To maximize the performance of the company, especially in parts of the payroll companies do a variety of ways to tackle this problem? Payroll was an administration payroll that is the work of the regular and including the most important part of a company that have employees. But in the operation payroll is still being done in a manual, reporting a difficult for the company, payroll data is not detailed, causing the performance of the company. In dealing with this problem then made payroll system app with the SCRUM. This method chosen because of the quickly and light in the development of the application and had to produce productivity and activities that was worth the high. There are three a role in the development of the SCRUM, namely the owner of the product, the SCRUM Master, and the developer. The owner of the products will define the needs of what is needed to run a business, then of the needs to be in transformation became one of the product backlog that is facilitated by a master of the SCRUM, then the product backlog this will altered back into the sprint backlog that will be developed by the developer. During the implementation of this requirement can change anytime and flexible with the consequences of development will be disrupted. The Output of the SCRUM this is the app provide module, consist of three modules, namely the administration of employees, absenteeism, and payroll as well as to report on any of the module.
\end{abstract}

Key words : SDLC, SCRUM, Payroll, Information System.

\section{INTRODUCTION}

Information Systems and Information Technology is technology resources, business processes, and strategic management so as to achieve company goals [1]. In planning design, operation and management of manufacturing systems, the concept of flexibility is the main choice in order to be responsive to new technologies [2]. Proper regulation of various resources and time on a task are key in dealing with planning and operational problems in manufacturing systems [3]. The priority of the manufacturing industry in facing the ever-changing situation is to find the right method, procedure, and measure, which allows it to survive in every environment [4]. The work environment is not only creating, but is built by workers within the company.

Many people in the world spend part of their adulthood to become someone who is paid by the company and for a variety of reasons they are based on it [5]. Workers hold a very important aspect in every organizational arrangement. Without human resources, achieving company targets will not succeed [6]. Employee transition is the most problematic thing to an organization in terms of losing qualified workers, furthermore recruitment and training cost [7]. The company is currently dealing with employee satisfaction, using a variety of motivational factors such as training, promotion, compensation for employees, performance bonuses, salary increases, bonuses, and employee empowerment [8].

The company is always provided compensation to his employee in the form of salaries or the payment of money, during the employees working at the company [9]. There is some form of the process of a contract with the candidate's employee; one of them is the pay. The pay can be accepted by employees after he finished do the work that have been determined to employees [10]. Employee performance can be increased due to salary, then that salary is very important. The salary increase should also be able to produce a better quality of life, motivation in the work, and also employee turnover can cause a decrease in production [11]. Decreasing company performance is the most undesirable thing for all stakeholders, so that it needs to be overcome by using a method.

Agile is a method that identifies problems and follows them up continuously and in a relatively short time, scrum is one of the frameworks found in the agile method. The purpose of this paper is to provide important factors of a successful implementation of the Scrum framework [12]. Scrum is one of the software development methods that are commonly used to help developers in managing this project appropriately [13]. Scrum uses an interactive approach, additional to optimize predictability and control risk to maximize opportunities for feedback [14].

Payroll in each company is the riskiest thing; this is caused by the dependence of an employee's life. In various companies in the world, work related leave and payroll handling are in 
form of a paper work, in order to diminish paper work and to overcome time consuming management [15]. An organization needs a system integrated payroll program to cause a positive impact on counting payroll [16]. Things like recording employee data, salary slips, allowances, leave, etc. can be done by the salary admin by using a salary program [17]. The problem is how to build a salary program that makes the salary process stronger in control, especially in salary calculation. These problems must be overcome by making a program that is suitable and easy to use for user. In the future, the existing salary process becomes more effective, efficient and provides more information for data users. Finally, the authors thank all those who have helped during the process of developing a salary program. It is hoped that this journal can help other parties in learning about the development of the payroll program.

\section{LITERATURE REVIEW}

This section briefly summarizes some of the important concepts that underlie this research, include of Payroll Information System, SDLC Model, and SCRUM Method Implementation.

\subsection{Payroll Information System}

Activity of the business and implementation of data processing can be mutually related continuous due to the existence of the payroll system. With this payroll information system, payroll division would be able to keep a record of employees including their personnel data, pay slips, allowances, tax, leave, etc. [18].

\subsection{SDLC model}

2.2.1 Waterfall: Progress on a software development can be viewed like a waterfall through the phases of the software execution which we call the waterfall model. This means making each phase in the software development process can be only started if the previous phase has been completed. The time of occurrence of the error on the previous phases of the waterfall model is not able to define back to the foregoing phase to handle the scope of work. Waterfall model is the approach best known and most widely used in software development. Usually this approach is used by developers working on the project in the absence of changes in the requirements needed [19].

2.2.2 V-Shaped: This is an extension of the waterfall model. slowly move down linearly, step by step process is bent upwards after the implementation phase and encoding, to form the typical form of $\mathrm{V}$. the main difference between the model V-shaped model and waterfall is planning initial testing in the model of the $\mathrm{V}$-shaped software requirements clearly defined and known, the technology and the software development already famous [19].

2.2.3 Prototyping: The model is referring to the activity if making prototype app software. For example, an incomplete version of the system is being developed for a demo to the user. The model is useful also to a visualization of some parts software to limit gaps miss understandings requirements customers by a team of developer [19].
2.2.4 Spiral: A model of this combination of two elements of the design and prototyping in stage, in an effort to incorporate the advantages of the concept of top-down and bottom-up. This SDLC model combines most of the prototype models and existing waterfalls. And also, the model is more using phase similar to the model waterfalls. Who are basically the order her the same, separated by planning, the judgment risk, and making prototype and simulation [19].

2.2.5 Iterative and Incremental: The model is developed to tackle weakness or depravation is on the model waterfalls. Starting from the beginning of planning and ends with the spread of by interactions cyclic [19]. Basically, the idea of a model of this is to develop the system through the cycle recurring (iterative) and on the portion smaller at a time, allowing software developer to take advantage of what learned during development or a version of the system before [19].

2.2.6 Extreme Programming (Agile): Extreme programming most suitable for the development of the system that requires the adaptability quickly to change of happened at the development of the applications. Extreme programming also suitable on the developer slightly and fit also on the same place in the development of the software. [20]. Extreme programming solves the project to be sub project. Namely, planning, development, integration, testing and dispatch [20], [21]

\subsection{SCRUM Method Implementation}

For optimizing predictability and control of the risk of the scrum follow philosophy iterative and incremental. The scrum has the principles of development in the process. Which are analysis, the requirements, design, the delivery, and development. The scrum also has a characteristic of management nimble [22].

\subsubsection{Main Roles of Scrum}

Product Owner is someone who is responsible to maximize the value of the products and the results of the team development, doing review of the sprint, and said the needs of the principal of the project and people representing the stakeholders;

Scrum Master is the team leader developer that makes sure that the team obeys theory, the practice, and the rules of the scrum;

Scrum Team, consisting of the professional who worked together in doing an analysis, implementation, design, testing, etc. [22].

\subsubsection{Artefacts}

Product Backlog - is the desire (Wish list / desired) product owner to the products that will be developed by the developer.

Sprint Backlog - is the most of the product backlog has agreed upon by product owner and the developer to be done in one sprint along the way.

Release Burndown - document measure the rest of saving product.

Sprint Burndown - this is the document measure the items sprint backlog left from time to time in sprint [22]. 


\subsubsection{Scrum Process Cycle}

Every activity that took place in the framework of the process of standards and time commonly referred to sprint. The number of sprints needed to finish every activity varies depending with the size and the complexity design. A project using the scrum still can start even if you just have a view. So shallow, this should have been clarified while the project was running [22].

\subsubsection{Time-Boxes}

This is a simple method commonly used during software development. In the Scrum method, this engineering applies to meetings and sprints that make it more objective. The time box components are: the meeting planning sprint, the meeting planning release, sprint, the scrum daily, the meeting review sprint, Sprint Retrospective [22].

\subsubsection{Daily Scrum}

In every day of a sprint, team held the meeting daily with each of the meeting with time 15 minutes in the same place and the same time follow progress of the development of the by using burndown chart to the tasks monitoring [22]. The scrum daily can increase the communication, identification, and removing barriers for development, highlighting and promote the decision making quickly, and raises the level of the knowledge of project development of the team. The Scrum master always holds meetings and ensures that all team members are present and remain to intervene briefly and strengthen rules [22].

\section{RESEARCH METHOD}

\subsection{Explanation of Scrum Roles}

The Scrum team has proven that its use is more effective in previous statements and provides products in an iterative and gradual manner and maximizes feedback [23]. The following method of research used in this paper shown in Figure 1. Research of Scrum Framework.

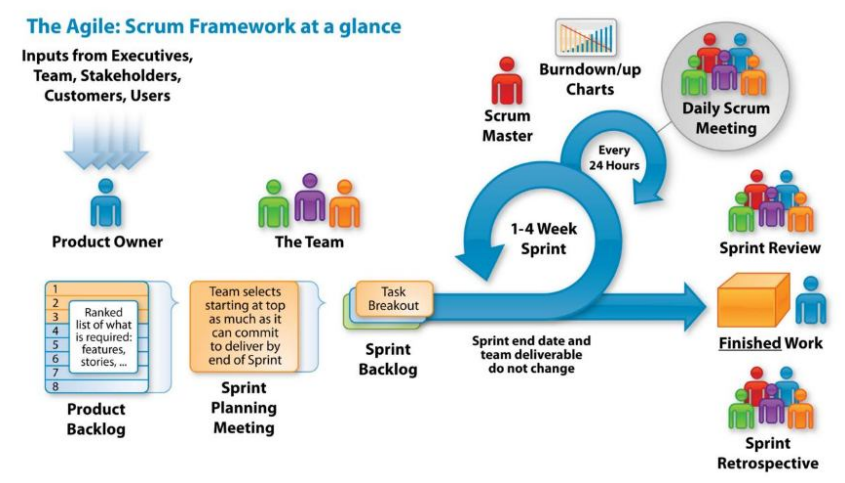

Figure 1: Research of Scrum Framework [14]

\subsubsection{Product Owner}

To maximize product value, responsibility lies with the product owner based on the results of the development team's work. The achievement of this will vary greatly in organizations, Scrum teams, and other individuals [23]. To manage product backlogs, the product owner is the only responsible user. To manage the product backlog, consist of:

- Expressing product backlog items as clearly as possible [24].

- Assess the results of the demonstration of the item whether it is in accordance with what was requested [25].

- Establish a priority Product Backlog based on input and needs from stakeholders [25].

- Form a Scrum Team in collaboration with The Scrum Master [25] and,

- Ensure that the development team to known the item level in the required Product Backlog [24].

He or she also cooperates with the Scrum team to analyses, define and detail each requirement [26]. To achieve success the entire organization must comply with the decisions of the Product Owner. Decisions made by the Product Owner will be seen in the content and request for Product Backlog, surely no one will be able to force the development team to work beyond the requirements [23].

\subsubsection{Development Team}

SDLC Methodology is a quite complex [29], which is why it is made simple by software [30]. The Development Team consists of several people who work and have different assignments for specific tasks [27]. This can work together in harmony to produce the products needed. Characteristics of the development team as follows:

- Determine the User Story or which requirements can be done in one sprint [28].

- Cross-functional, a team with each different set of skills is needed to make product improvements that can teach each other so that nobody is left behind in delivering the work [28].

- Each team member has special abilities, but accountability is still assessed as a whole team [32].

\subsubsection{Scrum Master}

Scrum Master Responsibility to the Development Team:

- Keep documentation for any changes made [26].

- Coordinating the team in the development [26].

- Establish a sprint planning meeting [24].

- Guiding Team Development where Scrum is not fully practiced and understood [23].

\subsection{Explanation of Artefacts}

The artefact is a guide in the Sprint Planning which contains two main points, namely the Sprint goal and Sprint Backlog [27]. The definition of the artefact may be different in other organizations but on average has the same meaning, which contains a list of priority items and how they are developed.

\subsubsection{Product Backlog}

The Product Backlog is a compiled list of functionalities that has been determined by the Product owner in the form of a User Story that has certain priorities [26].

\subsubsection{Sprint Backlog}

Sprint Backlog is a process that contains planning, prediction, and estimation of the work of Product Backlog 
(User Story) which has been analyzed based on the level of difficulty and importance [31].

\subsubsection{Increment}

All improvements to the finished Product Backlog Item, including the increase in the previous item, must be "Done" and meet the definition requirements as a "Done" product so that the work can support empiricism at the end of the Sprint. The improvement must function properly because the increase is the main objective of the Sprint Backlog, whether or not the Product Owner accepts it [23].

\subsection{Explanation of Time-Boxes}

From Scrum Methodology section Time Box consist of:
3.3.1 Release Planning: To improve understanding and communication the development team discusses the plans and objectives of publishing, general features and risks [25].

3.3.2 Sprint Planning: In Sprint Planning, the three core teams will hold a meeting to discuss and strategize how a Sprint Backlog will be carried out and done based on the priority level described in the Product Backlog [32]. Some complex Product Backlogs (User Story) will be broken down into small tasks that can be handled by the development team so that they can be done more efficiently [31].

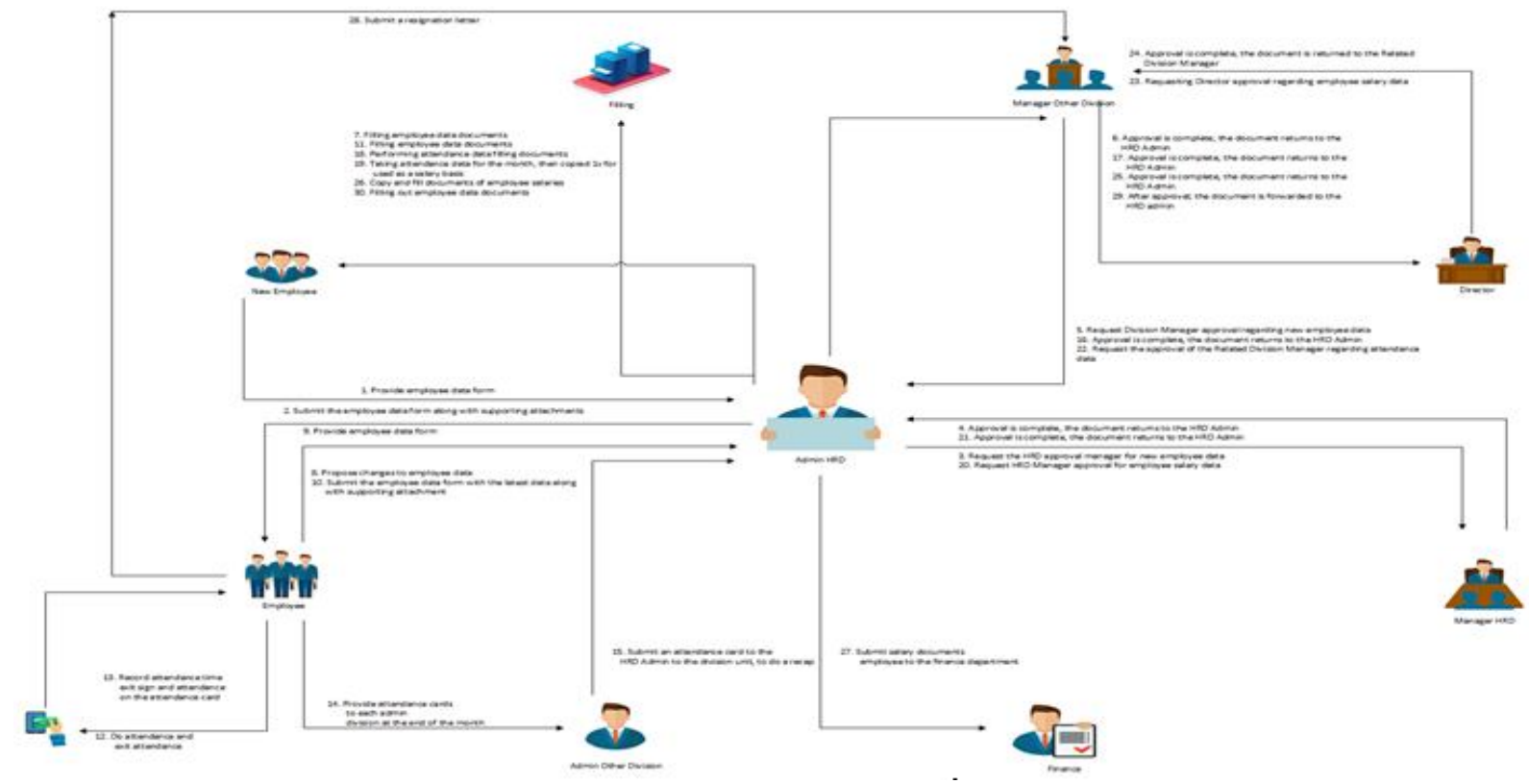

Figure 2: Current Business Process

3.3.3 Sprint: In Sprint it has one cycle (Iteration) which lasts for two to four weeks [21]. During the Sprint, there are several things that must be considered:

- That there were no changes that could endanger the main purpose of Sprint.

- The quality of the Sprint's Main Goals is not reduced.

- The scope can be reviewed and renegotiated between the Product Owner and the Development team [23].

3.3.4 Sprint Review: Sprint Review is a meeting between the development team including Scrum Master and the Product Owner, to discuss and inspect how the development of a product that has been developed from the Sprint Backlog [12].

3.3.5 Sprint Retrospective: The development team will discuss the progress of what is going smoothly and what should be improved further with the Scrum Master; in this discussion the Product Owner does not involve [22]. In the Sprint Retrospective, the Scrum Master guarantees that every meeting runs productively and positively. The objective of the Sprint Retrospective is to:

- Supervision how Sprint Work results relating to many people, relationships with the team, and the processes, and tools needed.
- To know and compile most items that has high possibility for product enhancement.

- Create planning how to implement progress to the way the Scrum team performs its duties.

The Scrum Master guarantee that the development process and practice run effectively and pleasantly in the next Sprint by motivating the Scrum Team and continuing to carry out these improvements in accordance with the framework of the Scrum process [23].

\subsection{Definition of "Done"}

Everyone must understand what "Done" means in a Product Backlog item. Even though each team has a different view, it must have the same perception. Use "Done" to assess when the work is completed on product upgrades [31].

\section{DEVELOPMENT AND RESULTS}

Based on the requirement and management of the company for development Payroll Information System an information source is needed to direct the development process better. The business process of the company that is still unable to implement the payroll information system can be seen from Figure 2. Current Business Process. 


\subsection{Development}

The author decided to develop a payroll system which included employee data, attendance data, and employee salary data. Implements the SCRUM framework with a team of 7 members, as follows:

- The Project Manager is the person who applies as a Master SCRUM and is responsible for the entire project.

- Business Analyst is a person who is responsible for analyzing business processes to be developed according to company needs.

- Systems Analyst is a person who is responsible for conducting feasibility studies, analyses, and designs that are the company's needs.

- Programmer 1 is a person who is responsible for translating results from system analyst into code / program, as well as testing the program so that it can be used.

- Programmer 2 is the person responsible for helping one programmer (1).

- Programmer 3 is the person responsible for helping one (1) and two (2) programmers

- Tester is a person responsible for testing what has been made by the programmer in accordance with the needs of the company.

The Scrum Team is divided into 3 parts, as follows:

- The Product Owner is the project owner or company.

- Scrum Master is a Project Manager.

- Development Team is a team consisting of one system analyst, one business analyst, three programmers, and one tester.

Table 1: Feature List Software Development Project

\begin{tabular}{|l|l|l|}
\hline No & Backlog Item & \multicolumn{1}{c|}{ Description } \\
\hline 1 & $\begin{array}{l}\text { Employee } \\
\text { Administration }\end{array}$ & $\begin{array}{l}\text { The mployee } \\
\text { administration module is } \\
\text { used to store employee data } \\
\text { (in and out) including } \\
\text { supporting documents (ID, } \\
\text { Tax, etc.). }\end{array}$ \\
\hline 2 & Attendance & $\begin{array}{l}\text { Attendance module is used } \\
\text { to record attendance data, } \\
\text { sickness, permission, } \\
\text { leave, and not entering } \\
\text { work without information. } \\
\text { From this module, the } \\
\text { employee can immediately } \\
\text { see the hours of attendance } \\
\text { in and out apply for } \\
\text { permission and leave. }\end{array}$ \\
\hline 3 & Salary & $\begin{array}{l}\text { The Salary Module is used } \\
\text { to make calculations and } \\
\text { record the salary of all } \\
\text { employees in a system } \\
\text { based on attendance data. }\end{array}$ \\
\hline
\end{tabular}

After the Team is formed, the following results from development with the SCRUM framework:
1) Product Backlog: The Product Owner provides a backlog list to the SCRUM Master which will then be adjusted to the SCRUM guidelines and will produce a Product Backlog. In total there are three (3) modules that will be developed, can be seen from Table 1. Feature List Software Development Project.

Table 2: Working Time Plan

\begin{tabular}{|l|c|c|c|}
\hline Roles & Days & $\begin{array}{l}\text { Hours / } \\
\text { Days }\end{array}$ & $\begin{array}{l}\text { Total Hours } \\
\text { (Sprint) }\end{array}$ \\
\hline Project Manager & 4 & 3 & 12 \\
\hline Business Analyst & 7 & 4 & 28 \\
\hline System Analyst & 8 & 4 & 32 \\
\hline Programmer 1 & 10 & 5 & 50 \\
\hline Programmer 2 & 10 & 5 & 50 \\
\hline Programmer 3 & 10 & 5 & 50 \\
\hline Tester & 7 & 4 & 28 \\
\hline
\end{tabular}

Table 4: Benefit Execution of Scrum Framework

\begin{tabular}{|c|c|}
\hline Case & Description \\
\hline $\begin{array}{l}\text { Estimated } \\
\text { Task Details }\end{array}$ & $\begin{array}{l}\text { By using the SCRUM framework, at the } \\
\text { end of the sprint for every } 2 \text { weeks the } \\
\text { details of the duties of each team member } \\
\text { are clearly detailed. }\end{array}$ \\
\hline Quality & $\begin{array}{l}\text { With a sprint, each team member gets } \\
\text { more encouragement in completing each } \\
\text { task. So, it will produce a quality } \\
\text { program. }\end{array}$ \\
\hline $\begin{array}{l}\text { Quality } \\
\text { Control }\end{array}$ & $\begin{array}{l}\text { Every end of the sprint, a Sprint Review } \\
\text { is carried out so that the quality of the } \\
\text { program can be justified. }\end{array}$ \\
\hline Risk & $\begin{array}{l}\text { Every Error that appears during the } \\
\text { development process is recorded in the } \\
\text { Monitoring Board in the developer } \\
\text { team's room for further re-evaluation } \\
\text { purposes. }\end{array}$ \\
\hline $\begin{array}{l}\text { Application } \\
\text { View }\end{array}$ & $\begin{array}{l}\text { At the end of each sprint, each team } \\
\text { member re-evaluates what changes have } \\
\text { been made. }\end{array}$ \\
\hline $\begin{array}{l}\text { Business } \\
\text { Change }\end{array}$ & $\begin{array}{l}\text { Business process changes will be } \\
\text { discussed later in the final sprint after the } \\
\text { application demo. }\end{array}$ \\
\hline $\begin{array}{l}\text { Customer } \\
\text { Feedback }\end{array}$ & $\begin{array}{l}\text { Each customer feedback will be } \\
\text { discussed in the final sprint process after } \\
\text { the customer sees the results of the } \\
\text { application demo. }\end{array}$ \\
\hline $\begin{array}{l}\text { Project } \\
\text { Monitoring }\end{array}$ & $\begin{array}{l}\text { By using the SCRUM framework that } \\
\text { provides monitoring boards, it can make } \\
\text { it easier for the development team to } \\
\text { make project monitoring easier }\end{array}$ \\
\hline $\begin{array}{l}\text { Live } \\
\text { (Production) }\end{array}$ & $\begin{array}{l}\text { With the use of the SCRUM Framework } \\
\text { it is possible to carry out development } \\
\text { directly, and can be completed per } \\
\text { product according to the product backlog } \\
\text { that has been made. }\end{array}$ \\
\hline
\end{tabular}


2) Sprint Planning: All members of the SCRUM team meet to discuss the chosen Product Backlog, every meeting is always held at the beginning of the Sprint.

This is done to ensure that each member understands the Product Backlog; the SCRUM Master has responsibility for this. About the proposed changes to the processes that occur can be seen from Figure 3 Proposed Business Process.

Table 5: Business Process Change

\begin{tabular}{|l|l|}
\hline \multicolumn{1}{|c|}{ Current Activities } & \multicolumn{1}{c|}{ Proposed Activates } \\
\hline $\begin{array}{l}\text { Employee data is stored } \\
\text { in filing. }\end{array}$ & $\begin{array}{l}\text { Employee data is stored in } \\
\text { the database. }\end{array}$ \\
\hline
\end{tabular}

\begin{tabular}{|l|l|}
\hline $\begin{array}{l}\text { Approval by Signing the } \\
\text { document }\end{array}$ & $\begin{array}{l}\text { Approval by Application } \\
\text { with less time consuming }\end{array}$ \\
\hline $\begin{array}{l}\text { Employee attendance } \\
\text { record still using paper }\end{array}$ & $\begin{array}{l}\text { Employee attendance } \\
\text { record are now stored in } \\
\text { database }\end{array}$ \\
\hline $\begin{array}{l}\text { Submission for approval } \\
\text { regarding leave, sickness } \\
\text { and permission via paper } \\
\text { signature by the manager }\end{array}$ & $\begin{array}{l}\text { Submission for approval } \\
\text { regarding leave, sickness } \\
\text { and permission via } \\
\text { Program with less time } \\
\text { consuming }\end{array}$ \\
\hline $\begin{array}{l}\text { Salary still counted by HR } \\
\text { admin }\end{array}$ & $\begin{array}{l}\text { Salary are now calculated } \\
\text { by the system }\end{array}$ \\
\hline
\end{tabular}

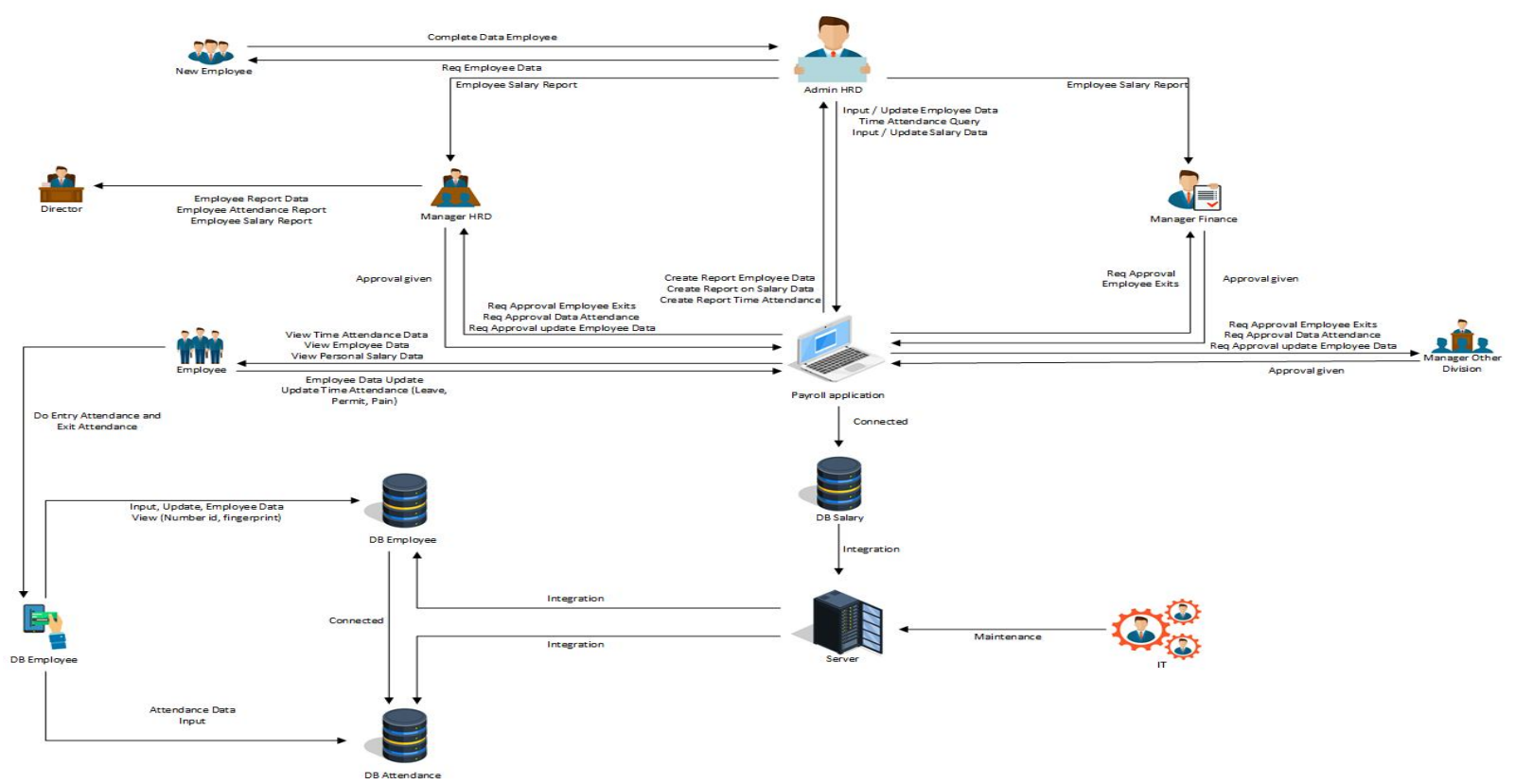

Figure 3: Proposed Business Process

Table 3: Sprint Backlog Feature.

\begin{tabular}{|c|c|c|c|c|c|c|c|c|c|c|c|c|c|}
\hline \multirow{2}{*}{$\begin{array}{l}\text { Feature } \\
\text { Backlog }\end{array}$} & \multirow{2}{*}{ Task } & \multirow{2}{*}{$\begin{array}{c}\text { Assigned } \\
\text { Team }\end{array}$} & \multirow{2}{*}{ ET } & \multicolumn{10}{|c|}{ The number of remaining hours / day Sprint } \\
\hline & & & & T1 & T2 & T3 & T4 & T5 & T6 & T7 & T8 & T9 & T10 \\
\hline \multirow{8}{*}{$\begin{array}{c}\text { Payroll } \\
\text { Information } \\
\text { System }\end{array}$} & $\begin{array}{l}\text { Business } \\
\text { Process } \\
\text { Design }\end{array}$ & $\begin{array}{l}\text { Business } \\
\text { Analyst }\end{array}$ & 5 & 4 & 3 & 0 & 0 & 0 & 0 & 0 & 0 & 0 & 0 \\
\hline & $\begin{array}{l}\text { Interface } \\
\text { Design } \\
\end{array}$ & $\begin{array}{l}\text { System } \\
\text { Analyst }\end{array}$ & 5 & 5 & 3 & 1 & 0 & 0 & 0 & 0 & 0 & 0 & 0 \\
\hline & $\begin{array}{l}\text { Database } \\
\text { Design }\end{array}$ & $\begin{array}{l}\text { System } \\
\text { Analyst }\end{array}$ & 5 & 5 & 4 & 2 & 0 & 0 & 0 & 0 & 0 & 0 & 0 \\
\hline & $\begin{array}{l}\text { Coding } \\
\text { Front End } \\
\text { and Back } \\
\text { End }\end{array}$ & $\begin{array}{l}\text { Programmer } \\
1\end{array}$ & 20 & 20 & 16 & 12 & 8 & 6 & 2 & 0 & 0 & 0 & 0 \\
\hline & $\begin{array}{l}\text { Coding } \\
\text { Front End }\end{array}$ & $\begin{array}{l}\text { Programmer } \\
2\end{array}$ & 20 & 20 & 18 & 14 & 9 & 5 & 1 & 0 & 0 & 0 & 0 \\
\hline & $\begin{array}{l}\text { Coding } \\
\text { Back End }\end{array}$ & $\begin{array}{l}\text { Programmer } \\
3\end{array}$ & 20 & 20 & 17 & 15 & 10 & 6 & 4 & 1 & 0 & 0 & 0 \\
\hline & \multirow[t]{2}{*}{ Testing } & $\begin{array}{l}\text { Project } \\
\text { Manager } \\
\end{array}$ & 3 & 3 & 3 & 3 & 3 & 3 & 3 & 1 & 0 & 0 & 0 \\
\hline & & Tester & 5 & 5 & 5 & 5 & 5 & 4 & 3 & 1 & 0 & 0 & 0 \\
\hline
\end{tabular}


The sprint time has been determined for 2 weeks, and each team member has their respective roles which can be seen from Table 2 Working Time Plan, regarding the division of working hours. If there is a change, the development process will be delayed until the next sprint.

3) Daily Scrum and Sprint: At the beginning of each day, the team will conduct an initial meeting to update information about the development of a salary program.

Not all members must attend meetings, but only related members who attend the meeting, can be seen from Table 3 . Sprint Backlog Feature.

4) Sprint Review: At the end of the sprint, the team conducts a Sprint Review.

In this case the team will invite the Product Owner to inform progress. Demo will be carried out by team members to the Team and Product Owner without using slide presentations but directly by demonstrating the product.

5) Sprint Retrospective: After conducting the Sprint Review, the team will conduct a Sprint Retrospective. At this stage the team conducts check in the team and makes an improvement plan to be carried out in the next sprint. This is done as a form of corrective action, and the Master SCRUM ensures that all team members can understand its purpose.

Most of benefit Implementation of Scrum Framework for payroll information system can be seen from Table 4 Benefit Execution of Scrum Framework.

Apart from the benefits of development, there are also several improvements in business processes, which can be seen from Table 5. Business Process Change.

For a complete illustration of the business processes that can now be seen in Figure 2 Current Business Process, and all changes are due to implementation in Figure 3 Proposed Business Process.

\section{CONCLUSION}

Based on the analysis and development of the payroll information system that has been done and the results of the discussion in the previous section, the following conclusions are obtained:

- Risk and quality degradation can be acknowledged more quickly during the development process.

- In the final sprint, changes to the business process and feedback from customers can be easily identified.

- Completion of the program can be done per product backlog.

- Program completion speed can be seen directly during the development process.

In the upcoming development, the application of new methods will be used in business changes and restrictions on feedback from customers will be carried out so that the action will interfere with the time target of the project.

\section{REFERENCES}

1. H. Tannady, J. F. Andry, F. E. Gunawan, and J. Mayseleste, Enterprise Architecture Artifacts Enablers for IT Strategy and Business Alignment in Forwarding Services, International Journal of Advanced Trends in Computer Science and Engineering, vol. 9, No. 2, 2020.

2. S. Sethi, Flexibility in Manufacturing: A Survey Flexibility in Manufacturing: A Survey, Int. J. Flex. Manuf. Syst., vol. 2, pp. 289-328, 2008. https://doi.org/10.1007/BF00186471

3. S. Cho and M. Erkoc, Design of predictable production scheduling model using control theoretic approach, Int. J. Prod. Res., vol. 47, no. 11, pp. 2975-2993, 2009.

4. M. Behun, B. Gavurova, A. Tkacova, and A. Kotaskova, The Impact of the Manufacturing Industry on the Economic Cycle of European Union Countries, $J$. Compet., vol. 10, no. 1, pp. 23-39, 2018. https://doi.org/10.7441/joc.2018.01.02

5. T. A. Judge, R. F. Piccolo, N. P. Podsakoff, J. C. Shaw, and B. L. Rich, The relationship between pay and job satisfaction: A meta-analysis of the literature, $J$. Vocat. Behav., vol. 77, no. 2, pp. 157-167, 2010. https://doi.org/10.1016/j.jvb.2010.04.002

6. E. Fokuo and J. K. Boakye, Training and Development : a Tool for Employee Performance in the District Assemblies in Ghana, Intern. J. Educ. Res., vol. 2, no. 5, pp. 513-522, 2014.

7. R. Loi, N. Hang-yue, and S. Foley, Linking employees' justice perceptions to organizational commitment and intention to leave: The mediating role of perceived organizational support, J. Occup. Organ. Psychol., vol. 79, no. 1, pp. 101-120, 2006. https://doi.org/10.1348/096317905X39657

8. A. Sohail, R. Safdar, S. Saleem, S. Ansar, and M. Azeem, Effect of Work Motivation and Organizational Commitment on Job Satisfaction: (A Case of Education Industry in Pakistan), Glob. J. Manag. Bus. Res., vol. 14, no. 6, pp. 41-46, 2014.

9. M. S. Chaudhry, H. M. Sabir, N. Rafi, and M. N. Kalyar, Exploring the Relationship Between Salary Satisfaction and Job Satisfaction: A Comparison of Public and Private Sector Organizations, J. Commer., vol. 3, no. 4, pp. 1-15, 2011.

10. A. Hameed, M. Ramzan, H. M. K. Zubair, G. Ali, and M. Arslan, Impact of Compensation on Employee Performance (Empirical Evidence from Banking Sector of Pakistan) Islamia University of Bahawalpur Research Scholars of Department of Management Sciences, Int. J. Bus. Soc. Sci., vol. 5, no. 2, pp. 302-309, 2014.

11. M. Zaini, A. Karim, S. Chan, and S. Hassan, Minimum Wage Policy and Country's Technical Efficiency, Int. J. Econ. Financ, vol. 6, no. 4, pp. 1729-1735, 2016. 
12. A. Ozierańska, A. Skomra, D. Kuchta, and P. Rola, The critical factors of Scrum implementation in IT project - the case study, J. Econ. Manag., vol. 25, no. 3, pp. 79-96, 2017.

https://doi.org/10.22367/jem.2016.25.06

13. A. Khosravi, T. Javdani Gandomani, and H. Fahimian, Introduction of Scrum in An Elite Team: A Case Study, J. Softw., vol. 12, no. 4, pp. 173-179, 2017.

14. M. Lee, Exploratory Study: Project Management in Scrum IT Project, August, 2016.

15. M. Singh, P. Singh, R. Singh, S. Singh, and S. Gupta, Leave and Payroll Management System, pp. 62-66, 2008.

16. S. Suryanto, Design and Analysis: Payroll of Accounting Information System, CommIT (Communication Inf. Technol. J., vol. 5, no. 1, p. 24, 2016. https://doi.org/10.21512/commit.v5i1.555

17. M. Singh, P. Singh, and R. Singh, S. Singh and S. Gupta, Automated Payroll System, IOSR Journal of Computer Engineering, pp. 62-66, 2016.

18. A. Kawale, H. Muthmare, P. Devghare, Y. Rajbhoj, R. Sonkusare, D. B. Khadse, Automatic Payroll Processing System, International Journal of Scientific Research in Science, Engineering and Technology, Vol. 4, Issue 4, 2018.

19. A. Y. Egwoh and O. F. Nonyelum, A Software System Development Life Cycle Model For Improved Students, Communication And Collaboration," vol. 8, no. 4, pp. 1-10, 2017.

20. I. G. N. Suryantara and J. F. Andry, Development of Medical Record With Extreme Programming SDLC, Int. J. New Media Technol., vol. 5, no. 1, pp. 47-53, 2018.

21. G. Dehondt Ii and A. Brandyberry, Programming in the eXtreme: Critical Characteristics of Agile Implementations, Inform. Softw. Eng. J., vol. 1, no. 1, 2007.

22. R. T. Nishijima, J. G. Dos Santos, The Challenge of Implementing Scrum Agile Methodology In A Traditional Development Environment, International Journal of Computers \& Technology, vol. 5, no. 2, pp. 98-108, 2013. https://doi.org/10.24297/ijct.v5i2.3529

23. K. Schwaber. The Scrum Guide. Softw. 30 Days, November, pp. 133-152, 2015.

24. M. Mahalakshmi and D. Sundararajan, Traditional SDLC Vs Scrum Methodology, vol. 3, no. 6, pp. 2-6, 2013.

25. A. Fallis, A Guide to the Scrum Body of Knowledge (SBOK Guide), vol. 53, no. 9. 2016.

26. S. Vasanthapriyan, Agile and Scrum in a Small Software Development Project- a Case Study, Proc. 7th Int. Symp., February, p. 7, 2018.

27. E. Neelima and N. D. S. K, A Study on SCRUM Agile Methodology And Its Knowledge Management Process, Int. J. Eng. Sci., vol. 2, no. 3, pp. 22-27, 2013.
28. S. Sachdeva, Scrum Methodology, Int. J. Eng. Comput. Sci., vol. 5, no. 16792, pp. 16792-16800, 2016. https://doi.org/10.18535/ijecs/v5i6.11

29. J. F. Andry, H. Tannady, and F. E. Gunawan, Purchase Order Information System using Feature Driven Development Methodology, International Journal of Advanced Trends in Computer Science and Engineering, Vol. 9, No.2, 2020.

30. V. N. Dolzhenkov, I. D. Maltzagov, A. I. Makarova, N. S. Kamarova, P. V. Kukhtin, Software Tools for Ontology Development, International Journal of Advanced Trends in Computer Science and Engineering, Vol. 9, No.2, 2020.

31. A. D. Rawsthorne and D. Shimp, Scrum 3.0, A White Paper from 3Back, 2017.

32. P. Adi, Scrum Method Implementation in a Software Development Project Management, Int. J. Adv. Comput. Sci. Appl., vol. 6, no. 9, pp. 198-204, 2015. https://doi.org/10.14569/IJACSA.2015.060927 